Advances in Social Science, Education and Humanities Research, volume 136

2nd International Conference on Social and Political Development (ICOSOP 2017)

\title{
Community empowerment Based Social Capital and Village Business Company (BUMDes)
}

\author{
Badaruddin 1; Kariono 2, Ermansyah 3; and Lina Sudarwati 4 \\ 1,2,3,4 University of North Sumatera \\ Corresponding Author: badaruddin.usu@gmail.com; badaru_69@yahoo.com
}

\begin{abstract}
Law No. 6 of 2014 on the Village states that one of the things that must be done by the village government is to empower the village community. Through community, empowerment is expected to realize the independence of society, both economically, socially, culturally, and politically. In relation to the empowerment of rural-oriented villagers, the Village Law also states that the Village Business Company(BUMDes) is an economic institution that can realize the economic independence of the village. In addition to economic orientation, BUMDes is also expected to be a tool for knitting together (collectivity) of village communities. To realize these expectations, it is necessary to empower the village community, where BUMDes can be used as a tool in the process of empowerment. In order for the empowerment of village communities through BUMDes to run well, in the establishment and implementation, the socio-cultural values (local wisdom) of village communities should be utilized and empowered. In this context, the Village Law has responded to the use of socio-cultural values for the empowerment of village communities. The response of Law No. 4 of 2014 on the village against local wisdom can be seen from the philosophy of the Village Law that revives the socio-cultural values (local wisdom) of village communities that can be realized through the potential of social capital that exists.
\end{abstract}

Keyword: Village Community Empowerment; Village business company (BUMDes), Social Capital.

\section{INTRODUCTION}

Indonesia's National Development aims to create a prosperous and just society. To realize these objectives, the government seeks to make various policies and development programs, both oriented towards village development or cityoriented development. The situation shows that city development is faster than village development. This can be seen from the increasing number of urbanization from year to year, and the low interest of the younger generation to settle in the village. In other words, the ongoing development has resulted in urban biases, ie more development on urban development, so that village development is less attractive for villagers to stay in the village. The cake of development the village is less than in urban areas, consequently, the village is getting left behind, whereas the village has a strategic role in supporting the national development.

Within the framework of village development acceleration, village community empowerment efforts have been widely implemented, ranging from the establishment of cooperatives (Village Unit Cooperation-KUD), Village Assistance Programs
(InpresDesaTertinggal-IDT), to the National Community Empowerment Program(Program Nasional PemberdayaanMasyarakat- PNPM). These efforts have not shown maximum results, although the PNPM program is widely referred to as one of the relatively successful programs compared to other programs that have ever existed.

Community empowerment according to Zubaedi (2014) is an effort to improve the dignity of the poor society, so that they can escape from the poverty trap and backwardness. In line with Zubaedi's opinion, the empowerment of the community, especially the village community is needed in the framework of the equitable distribution of development results, so the view that development so far is urban biased can be ignored. To realize the independence of the village community and to realize the wider autonomy of the village as mandated in the Law on Regional Autonomy (Law No. 22 of 1999 regarding Regional Government revised by Law No. 32 of 2004 on Regional Government), the Government together with the House of Representative. Law No. 6 of 2014 on the Village. The Village Law is expected to reduce the imbalance of rural-urban development.

Law No. 6 of 2014 on The Villages that have a philosophy for the realization of village self- 
reliance. The Law has been implemented in 2015 and is currently (2017) already entering the third year of implementation of the Law. The dynamics of village development began to be seen with the enactment of the Law. In addition to providing wider autonomy for villages in managing village development, the Village Law also mandates the Central Government to allocate Village Funds sourced from the National Revenue and Expenditure Budget (Anggaran Pendapatan Belanja Nasional-APBN). In order to accelerate village development, the Village Law also mandates that the village establish a Village Business Company (BUMDes). Although the Village Law mandates the establishment of $\mathrm{d} B U M D e s$, the results of research conducted Badaruddin, et al. (2016) indicates that not all villages studied have BUMDes. The three villages of studies, only one village has established BUMDes, with the scale of economic activity still very limited. Although only one village has established BUMDes from the three villages studied, but the spirit of the other two villages to immediately form a very strong BUMDes. The Village Busines Company is expected to be a leverage for the progress of a more independent village. As a village economic institution, the formation ofBUMDes is not only oriented to the accumulation of financial capital but must pay attention to other capital, such as social capital. As Zubaedi (2014) pointed out, the community development and empowerment program are crucial to perfecting the limitations and shortcomings of the pro-growth development model offered by the government. One of the characteristics of the development model of progrowth according to Zubaedi is the emphasis on the efforts of physical capital accumulation (physical capital) is centralized and tend to ignore aspects of its relationship with other capital-capital such as natural capital, human capital, and social capital. According to Rumangit (2002), the imbalance between capital has given birth to multicrisis in development during this time.

Village Owned Enterprises as one form of formal (economic) institution in the village (Badaruddin, 2016), ideally should grow through the utilization of potential social capital in the village. This is important for the sustainability of the economic institutions. As Zubaedi (2014) puts it, social capital assumes the importance of relationships in economic affairs. Companies, government agencies, industrial institutions at the national regional level can function more efficiently if mutually respectful and trusting relationships are mutually respected. Within this framework, it can be said that social capital fertilization can contribute to economic development because it contains networks, norms, and beliefs.

Village Busines Company as one of the village economic institutions mandated in Law No. 6 of 2014 in the Village can be one means for the empowerment of village communities. An important prerequisite that must be considered in the formation of village economic institutions (BUMDes) is the utilization of potential social capital in the village. In this paper will be discussed, among others: 1) The concept of community empowerment (village) and Village Busines Company(BUMDes); and 2) The concept of social capital.

\section{COMMUNITY EMPOWERMENT (VILLAGE) AND VILLAGE BUSINESS COMPANY (BUMD)}

The discourse and practice of community empowerment actually have been going on for a long time, but until now still leaves many problems. This can be seen from the poverty condition of the community which shows its powerlessness. The substance of community empowerment approach according to Sajogyo (1982) and Mubyarto (1984) is to place society as the main actor in all development series. Empowerment by placing society as subject to identify problems and participate in program planning will result in high self-reliance. The views of Sajogyo and Mubyarto are in line with the spirit of Law no. 6 The year 2014 on the Village which also aims to make the village become independent.

In line with the spirit of village autonomy, Nugroho (2012) states that regional development through autonomous decision-making mechanism is believed to be able to respond to actual problems that will often arise in the high intensity of resource allocation and development. Autonomy in the administration of development is perceived to be more relevant in line with the social and ecological diversity (bio-social diversity) in a region. The independence of villagers in building their village is a must. Making the community selfsufficient often requires help from outside groups. That is, there needs to be intervention from outside parties that direct and mention villagers become independent or powerless. The process of 
making the powerless society empowered is what is called the concept of "empowerment".

Papilaya in Zubaedi (2014) mentions that empowerment is an effort to build people's capacity, by encouraging, motivating, awakening awareness of their potential and working to develop that potential into action. While Chambers (1994) defines the empowerment of society as a concept of economic development that encapsulates social values. This concept reflects the new paradigm of human-centered, participatory, empowering and sustainable development. Furthermore, Ife (1997) states that community empowerment efforts need to be based on the understanding that the emergence of community powerlessness due to the community has no power. The Ife further identifies several types of strengths that people have and can be used to empower them:

1. The power of personal choice, ie empowerment is done by giving the public the opportunity to make a personal choice or a chance to live better.

2. Strength in determining their own needs, namely empowerment is done by assisting them to formulate their own needs.

3. The power of freedom of expression, ie, community empowerment is done by developing their capacity for free expression in the form of political culture.

4. Institutional strength, namely empowerment is done by improving the accessibility of the community to the institutional education, health, family, religious, social welfare system, government structure, media and so forth.

5. The strength of economic resources, namely empowerment is done by increasing accessibility and control of economic activity.

6. Strength in reproductive freedom, that is, empowerment is done by giving freedom to the community in determining the process of reproduction.

In line with what is said by Ife, the effort of village community empowerment is an effort to give the people the power to be powerless. The concept of community empowerment that has been described can be used as a tool to see (photograph) the phenomenon of BUMDes formation as one of the media or means to empower the economy of the village community. The presence of BUMDes also became part of the implementation of Law No. 6 of 2014 on the Village.

The empowerment of rural communities through the presence of BUMDes becomes important given the many problems in the community empowerment work that becomes the obstacle so that the empowerment effort becomes not maximal. As the results of research conducted by Darwis, et al. (2011) who concluded that institutional establishment is not an easy task, either from the side of the initial establishment or from the institutional side itself. It takes time to establish the existence of the poor and other related institutions with the goal of empowering the poor and fostering rural economies.

The practice of community empowerment has been done a lot, such as community service performed by Suandi, et al. (2011) entitled "Community Empowerment through Development of Organic Agriculture Based Trikolimtan in Full River City of Jambi Province". The result of the community's dedication came to the conclusion that the community empowerment program that was done succeeded in increasing the community competence and increasing the farmer's income. The results of Widjajanti (2011), under the title "Community Empowerment Model", concluded that the process of community empowerment in Desa Sumber Rahayu had a significant effect on community empowerment. The results of the devotion and the results of the study illustrate that the empowerment of the community (village) is one effort that can improve the welfare of rural communities. The context of this study will look at the empowerment model through BUMDes.

\section{THE CONCEPTION OF SOCIAL CAPITAL AND COMMUNITY EMPOWERMENT (VILLAGE)}

In line with the change of views on development capital, that the success of development is not only determined by the availability of financial capital but also very determined by the availability of other development capital, including social capital. Suwandi (2011) mentions that social capital is a form of social and economic networks in a society that occurs between beneficial and beneficial individuals and groups. The concept of social capital according to Fukuyama in Ibrahim (2002), was first put forward by Lyda Hudson Hanifan (1916) to describe the Rural School Community Centers. This concept is then developed and widely 
used by researchers to analyze various phenomena that exist in the midst of society, such as the phenomenon of development; organizational phenomena; the phenomenon of empowerment (development) of society; government phenomena; political phenomena and so forth.

Ostrom (1993) uses the concept of social capital to highlight the phenomenon of development in Third World Countries. In this study using this concept of social capital, Ostrom mentioned that development using social capital showed better success rates, so he concluded that social capital is one of the prerequisites for the success of a development program. Badaruddin, et al. (2016) mentions that strong social capital is manifested in the form of community associations, norms, trusts and networks at different levels.

In relation to the organizational phenomenon, Rose (1999) in her research in Russia found that social capital is a key element for the working of informal organizations in society as an alternative to formal organization. Rose's findings show that social capital is an important prerequisite for organizational success. The Village Act of 2014 shows explicitly the formal village organization as part of the Implementation of the Act. In addition, the Village Act in 2014 incorrectly requires the growth of informal village organizations in support of good governance in village governance. In the context of this research, the presence of BUMDes in the midst of village communities is a form of formal organization (an economic institution in the village) that aims to empower the economy of the village community. This shows that social capital has linkages to empowering village communities. This is in line with the research findings of Suandi (2011) who found that social capital variable (local association and community character) both directly and indirectly have a positive effect very significantly on the level of objective economic welfare and subjective economic prosperity of the family. That is, the higher the level of social capital owned by the family then the better the level of their welfare. The findings of this study provide the assumption that the utilization of social capital in the formation and operation of BUMDes will give maximum results from the existence of BUMDes, in the sense of its sustainability and its contribution to improving the social and economic welfare of rural communities.
Putnam and Fukuyama who developed social capital according to Spellerberg (1997) put forward a different definition of social capital, but the definition of both has a close relationship. Putnam defines social capital as the appearance of social organizations such as networks and trusts that facilitate coordination and cooperation for mutual benefit. While Fukuyama defines social capital as an ability that arises from the existence of trust in a community. Fukuyama (1995) also mentions that the core element of social capital is trust.

The study using the social capital concept in the phenomenon of community empowerment was also conducted by Badaruddin (2006) who studied about "Social Capital and Development of Models of Social Capital Transmission in Efforts to Improve Family Welfare (Study on Three Rubber Farmers Community in Rao Sub-district Pasaman District West Sumatera)". From the results of the study, it was found that "the rubber sale organization with auction system in the village was formed due to the availability of social capital in the village, and the ability of local communities to utilize and utilize social capital. The findings of Badaruddin's research reinforce Putnam's (1993) conclusion that the elements of social capital (trust, norm, and social network) tend to be selfreinforcing and cumulative, which means that the social capital stock will grow (cumulative) when used.

The Research on Badaruddin (2009) on "Social Capital Models of Alternative Social Responsibility (CSR) Implementation in North Sumatra (Study on Three Corporates: SOE, PMDN, and PMA)" found that CSR implementation by corporates has not fully utilized social capital, which has an impact on the outcome of the CSR program. From the results of research conducted offered an alternative model of CSR-based social capital implementation through "Collaboration Work Model" as shown in Figure 1. 


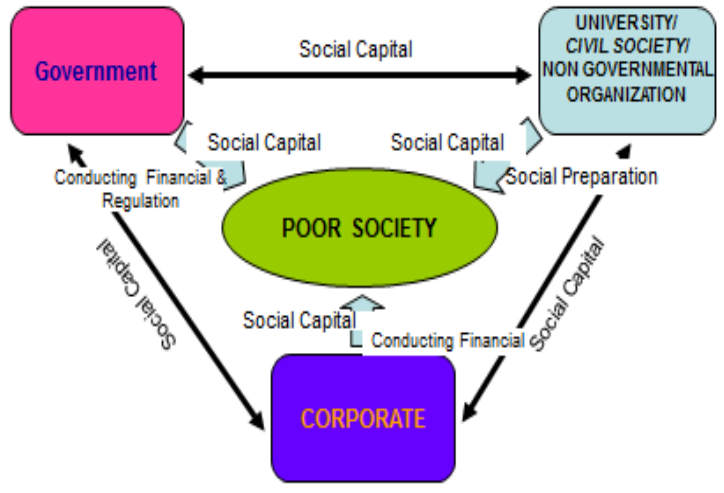

Figure 1. The Model Of Collaborative Working for Community Empowerment

Through CSR Program That Utilizes Social Capital

The Results of Research Badaruddin's, et al. (2016) entitled Model Implementation of Law Number 6 of 2014 on Social Capital-Based Village in North Sumatra "concludes that the village actually has a wide range of potential social capital that can be utilized in the context of the implementation of Law No. 6 of 2014 about the Village which can be grouped into two forms of social capital potential: first, the potential of social capital in the form of value (value); and 2) the potential of institutional-based social capital (formal and non-formal institutions). In the context of this research, the potential of social capital will be used as material to see BUMDes as part of empowering village communities.

The World Bankas one of the world's financial institutions that mostly channel aid, especially for third world countries, are also interested in the results studies that use the concept of social capital (see Dasgupta and Serageldin, 1999). The World Bank defines social capital as the norms and social relationships inherent in the social structure of society that is able to coordinate actions in achieving goals. This definition illustrates that the effectiveness of goal attainment can only be realized when social capital is owned by cooperating people or groups.

Primadona (2012) in his research entitled "Strengthening Social Capital for Community Empowerment in Rural Development (Kelompok Tani Kecamatan Rambatan) found a number of factors that led to the successful strengthening of social capital in farmer groups with the government program and factors causing failure of social capital strengthening in groups farmers with government programs. Factors that cause success are:

1. Participation of members in groups is based on the desire of the members of the group or the individual himself to move forward without any compulsion from any party.

2. Government programs granted to groups have been accompanied by structured ways so that they gain the knowledge they can absorb to assist them in carrying out their farming activities. This can be done with the counseling provided by PPL officers in accordance with the needs of farmer group members so far.

3. The social sense that is in the group should be given motivation by the government, for example by facilitating their difficulties in conducting their farming activities. The government can provide capital assistance through revolving funds, or build irrigation for rice flows or other farming activities.

4. The most visible of the farmer groups-the above farmers groups are the high trusts or trusts within the group, either trusting the government, trusting the group leader or trusting with the group members. Because according to some literature that the authors read the element of social trust capital is an important element in social capital.

5. Farmer groups-farmer groups above in carrying out their business activities in large part has been supported by adequate facilities in carrying out its activities.

6. In addition to the above matters which led to the strengthening of social capital within the group is a sense of mutual care and care of fellow members of the group and is also based on the level of the lordship of a very strong member, so that in building the group the value of religion also affects the capital social members or groups.

7. The background of the population and community in the research area is generally farmers so that if there are programs given by the government they are very enthusiastic in implementing it,

In addition to factors that cause success, Primadona (2012) further mentioned that there are several factors also cause failure of social capital strengthening in farmer groups studied are:

1. The farmer group formed by its membership is not based on individual desires by members or 
individuals but is more motivated by the temporary benefits gained from government programs.

2. Awareness of members to move forward with assistance or programs provided by the government is lacking.

3. The sense of community trust in the farmer group is less, whereas as we know the element of trust is the most important social capital and very important to be built both in individuals and in groups.

4. So far because of the community's strong access to the government so that if there are government programs, these farmer groups get it easily so that the rewards for progress and the desire to strive for less with government programs.

The results of this Primadonna research reinforce the assumption that the empowerment of rural communities will only work well if in community communities have a strong social capital so that social capital is utilized in the social relationships they build. Conversely, if the social capital content is weak in a community, the community empowerment will become slower. Therefore, in the community empowerment programs, the potential of social capital in the village community should be utilized and utilized so that the success of the empowerment program can be better. In this context, the presence of Village Owned Enterprises (BUMDes) is expected to become a medium to utilize and utilize the potential of existing social capital, both in the formation and implementation of the BUMDes.

\section{CONCLUSION}

Community empowerment (village) in Indonesia is a must and urgent to do if the village does not want to continue to lag behind the city development. From the point of view of the regulation, the empowerment of rural communities is very possible with the issuance of Law No. 6 of 2014 on Villages that have a philosophy for the realization of village independence.

To realize the noble ideals of the Village Act, then the village community empowerment programs are expected to be a priority for village development. In order to empower the village community, the potential of social capital that existed in the village community should be utilized and utilized so as to provide better results for the welfare (economic, social, and cultural) for all villagers. Village Owned Enterprises (BUMDes) is one means that can be utilized by villagers to achieve better welfare for them.

\section{REFERENCES}

Badaruddin. 2006. Modal Sosial dan Pengembangan Model Transmisi Modal Sosial Dalam Upaya Peningkatan Kesejahteraan Keluarga (Studi Pada Tiga Komunitas Petani Karet di Kecamatan Rao Kabupaten Pasaman Sumatera Barat). Laporan Penelitian. Hibah Bersaing. DP2M-Dikti. Mendiknas.

2009. Model Implementasi Corporate Social Responsibility (CSR) Berbasis Modal Sosial (Social Capital) di Sumatera Utara (Studi pada Tiga Korporat: BUMN, Swasta Nasional, dan Swasta Asing). Laporan Penelitian. Hibah Tim Pascasarjana, DP2M-Dikti, Mendiknas.

Badaruddin dan Ermansyah. 2016. Model Implementasi Undang-Undang Nomor 6 Tahun 2014 Tentang Desa Berbasis Modal Sosial di Sumatera Utara. Laporan Penelitian. BPPTN-USU. LP USU.

Badaruddin dan Henri Sitorus. 2016. "Social Capital And Climate Change Mitigation And Adaptation Through Promotion And Adoption of Green Technology. Dalam Jurnal Indikator Sosiologi Program Studi Sosiologi Universitas Sumatera Utara. Vol. 1. No. 1/November 2016.

Chambers, Robert. 1994. The Origin and Practice of PRA. Dalam World Development. Vol. 22. No. 7.

Darwis, Valeriana dan I Wayan Rusastra. 2011. Optimalisasi Pemberdayaan Masyarakat Desa Melalui Sinergi Program PUAP dengan Desa Mandiri Pangan. Dalam jurnal Analisis Kebijakan Pertanian. Vol. 9. No.2. Juni 2011. 
Dasgupta, Partha dan Ismail Serageldin (ed.). 1999. Social Capital: A Multifaceted Perspective. Washington: The World Bank.

Fukuyama, Francis. 1995. Trust: The Social Virtues and The Creation of Prosperity. New York: The Free Press.

Ibrahim, Linda D. 2002. Kehidupan Berorganisasi Sebagai Modal Sosial Komunitas Jakarta, Jurnal Masyarakat. No. 11. Depok: LABSOSIO FISIP UI.

Ife, Jim. 1997. Community Development: Creating Community Alternatives-Vision, Analysis and Practice. Melbourne: Addison Wesley Logman.

Mubyarto. 1984. Strategi Pembangunan Perdesaan. Yogyakarta: P3PK UGM.

Nugroho, Iwan dan Rokhmin Dahuri. 2012. Pembangunan Wilayah, Perspektif Ekonomi, Sosial, dan Lingkungan. Cetakan Kedua (Edisi Revisi). Jakarta: LP3ES.

Putnam, Robert D. 1993. Making Democracy Work: Civic Tradition in Modern Italy. Princeton: Princeton University Press.

Rose, Richard. 1999. "Getting Things Done in an Antomodern Society: Social Capital Networks in Rusia". Dalam Partha Dasgupta dan Ismail Serageldin (ed.). Social Capital: A Multifaceted Perspective. Washington: The World Bank.

Rumangit, Grace A.J. 2002. Alternatif Model Pembangunan Indonesia Menghadapi Era Globalisasi (Suatu Kajian Empiris). Makalah Falsafah Sains (PPs-702), Program Pascasarjana Institut Pertanian
Bogor. http://rudyt.tripod.com/ sem2_012/ grace_rumagit.htm.

Ostrom, Elinor. 1993. Crafting Institution, SelfGoverning Irrigation Systems. San Fancisco: ICS Press.

Sajogyo. 1982. Bunga Rampai Perekonomian Desa. Jakarta: Yayasan Obor Indonesia.

Spellerberg, Anne. 1997. Towards A Framework For The Measurement of Social Capital. Dalam David Robinson (Ed.). Social Capital and Policy Development. Wellingtone: The Intitute of Policy Studies.

Suandi. 2011. Hubungan Modal Sosial dengan Kesejahteraan Ekonomi Keluarga di Daerah Pedesaan Jambi. Dalam Jurnal Komunitas: Research and Learning in Sociology and Anthropology. Vol. 6. No. 1. http://journal.unnes.ac.id//nju/index.ph $\mathrm{p} /$ komunitas.

Suandi, Jasminarni, Trias Novita, Evita, dan Suryono. 2011. "Pemberdayaan Masyarakat Melalui Pengembangan Pertanian Organik Berbasis Trikolimtan di Kota Sungai Penuh Provinsi Jambi". Dalam Jurnal Pengabdian pada Masyarakat. Nomor 52/2011.

Widjajanti, Kesi. (2011). "Model Pemberdayaan Masyarakat". Dalam Jurnal Ekonomi Pembangunan. Vol. 12. No. 1/Juni 2011.

Zubaedi. 2014. Pengembangan Masyarakat: Wacana dan Praktik. Cetakan Kedua. Jakarta: Kencana Prenadamedia Group. 